\title{
VALUING THE ENVIRONMENT: A BRIEF SURVEY OF VALUATION TECHNIQUES
}

\section{DR. MOTHI GEORGE}

Assistant Professor, Department of Economics, Government College, Ambalapuzha, Kerala

\begin{abstract}
The absence of markets for environmental goods and services and market failure makes environmental resource allocation and utilization difficult. It is of great importance to provide economic values to these resources and thereby regulating their use. Valuation techniques help to generate monetary values to environmental goods and services. The article gives a brief survey of the important valuation techniques that are widely used for valuing environmental resources.
\end{abstract}

KEYWORDS: Economic Valuation, TEV, WTP, WTA, Hedonic Pricing, Contingent Valuation

\section{INTRODUCTION}

Economic valuation of resources needs to be undertaken, when the market fails to generate the true prices of the resource in question. An economic valuation helps compute the true price of a resource. Market failures are common for environmental resources mainly due to externalities which cause difficulties in valuation. Economic valuation of environmental resources can help make decisions on resource utilization and allocation more meaningful. The price paid for an economic good or service shows the consumer's Willingness to Pay (WTP). An economy provides a mix of marketed and non-marketed goods. Environmental goods and services come under the category of non-marketed goods. Economic valuation means giving monetary values to the non -market goods and services and the economic valuation of the environment means giving monetary values to environmental goods and services. In a market the individual will buy a good when he finds that the WTP is greater than the price. Assigning monetary values for environmental goods means finding a measure of WTP or WTA (willingness to accept a compensation for giving up the benefit) for an environmental good. Economic valuation is all about finding a WTP or WTA measure when market is incapable of providing that information.

\section{Economic Values of Environmental Assets}

To find out the economic value of the environment, the concept of Total Economic Value (TEV) is used. Identifying and determining the economic values of environmental resources and measuring these values are a difficult process. The goods and services provided by the environment include recreation and tourism, plant and wildlife habitat, genetic resources, water supply, protection against natural disasters, etc. Many of these goods and services are not traded on commercial markets and therefore have no market value. The values of non-market goods and services have to be measured and expressed in monetary terms, so that they can be treated as commercially traded components. Figure 1 show the various concepts associated with TEV. 


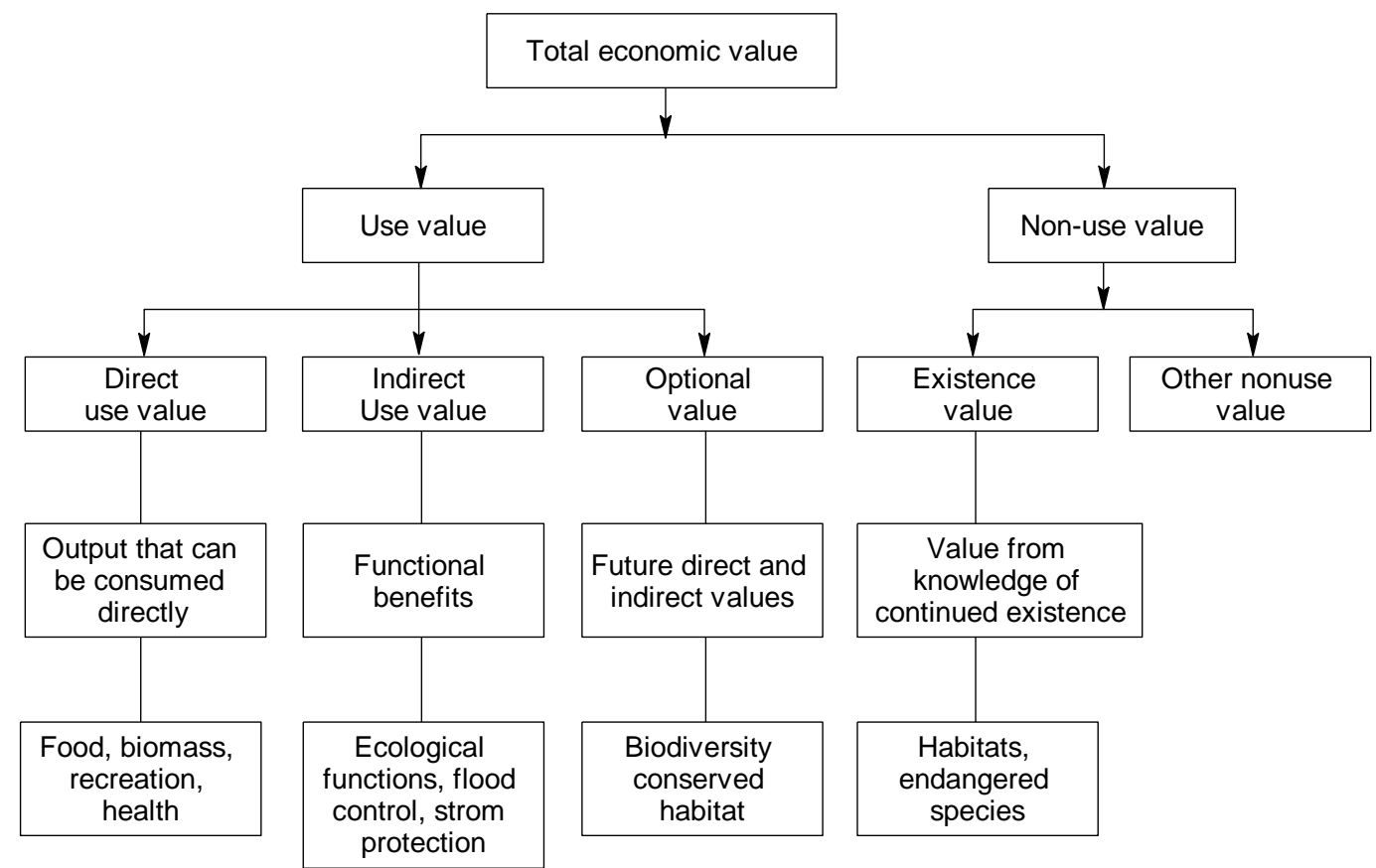

Source: JepmaC.J and M.Munasinghe (1998)

Figure 1: Concepts associated with TEV

TEV is the sum total of the use and non-use value of the environmental good. The use value refers to the values derived from the actual use of the resource and includes direct use values, indirect use values and the option values. Direct use values refers to the direct use of a protected area, for instance, for activities such as recreation, tourism, natural resource harvesting, hunting, gene pool services, education and research. These activities can be commercial, meaning they are traded on a market or non-commercial, meaning there is no formal or regular market on which they are traded. Indirect use value means the values derived from the indirect use of a protected area and option values are values derived from using the good in the future. Non-use value refers to the values that are not associated with the actual use of the resource include existence values and bequest values. The existence values is the value derived from the knowledge that a good is existing and bequest values are those which is derived by the fact that others are benefiting or will benefit from the good. Non-use values are particularly difficult to measure. With the emergence of environmental economics the link between ecology and economics is more visible. Economists and ecologists have now a common interest in understanding the economic contribution of the environment.

\section{Non-Market Valuation}

The valuation of environmental issues like biodiversity loss, global warming, and species extinction is highly complex. Economists have developed new ways for calculating the economic and social values of environment. In the environmental context, it is necessary to impute a valueto the environmental good or service. Economic valuation tries to measure human preferences for or against changes in the state of environments (Pearce1992). In economic valuation the theoretical statement is that preferences are already formed and economists try to find out the true underlying preference about environmental goods and services (Clive L.Spash et al 2001). Environmental economics has developed techniques whereby such values can be imputed. In the market place individuals exercise choice by comparing their WTP with the price of the product. They purchase the good when their WTP exceeds the price, and not otherwise. Imputing values 
involves finding a measure of WTP for environmental quality. Economic valuation involves finding a WTP measure in circumstances where markets fail to reveal that information directly. The purpose of economic valuation is to reveal the true costs of using up scarce environmental resources. Environmental valuation is thus forms an integral part in the determination of the balance between conservation and development and in the choice of environmental standards.

\section{Overview of Methods for Environmental Valuation}

A variety of economic techniques and models have been developed for environmental valuation. Valuation methods can be classified as follows.

- $\quad$ Physical linkage methods(Scientific)

- $\quad$ Abatement cost methods(Technical)

- Behaviourial linkage methods(Economic)

A large number of techniques have been developed over the years for the purpose of environmental valuation.

Figure 3.2 shows the various methods used for the valuation of the environment.

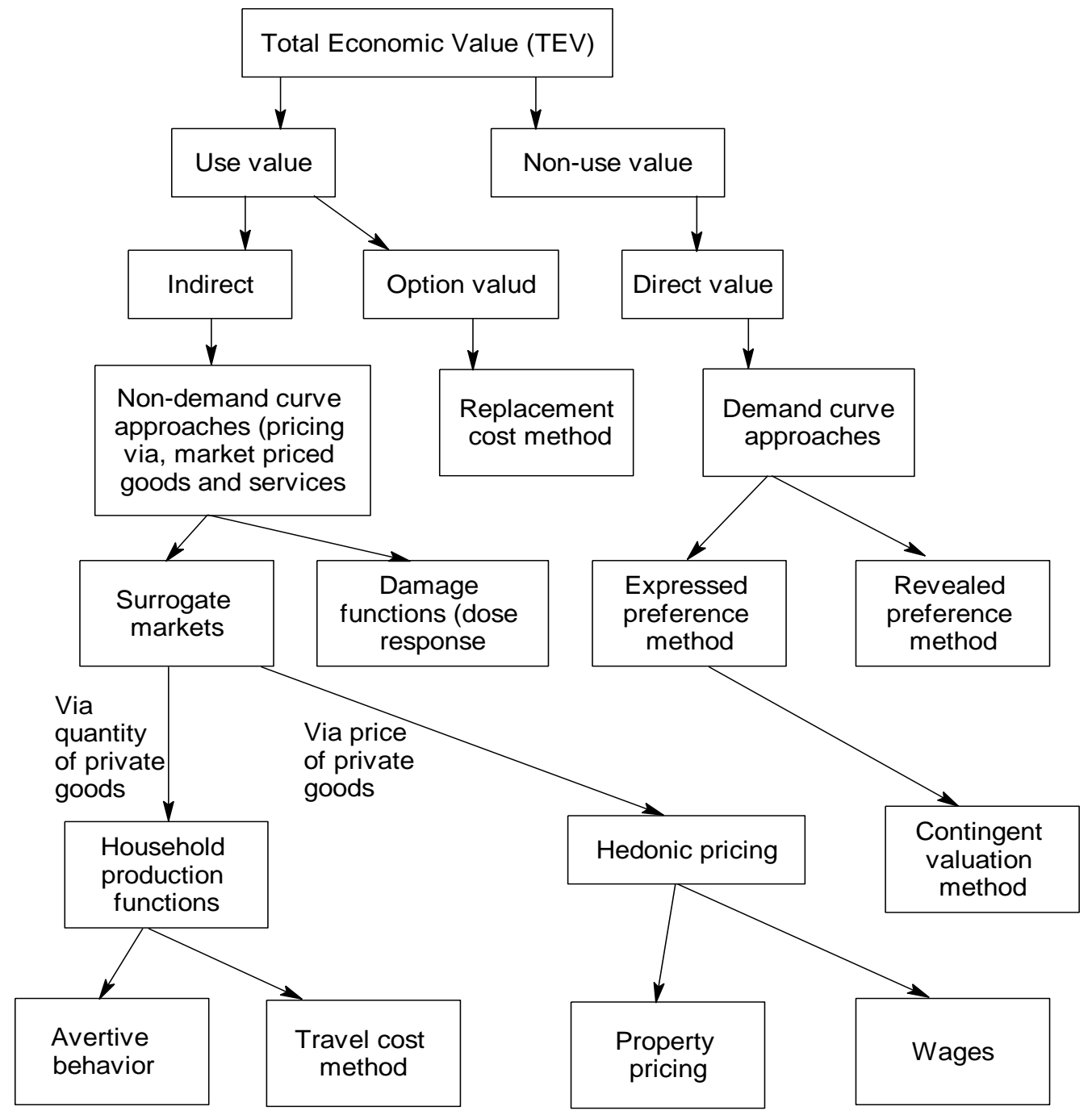

Source: V. Santhosh et al

Figure 2: Methods for Valuation and Pricing Ecological Goods and Services 
Different methods for eliciting both market and non-market values from people for environmental goods and services have been developed over the last few decades. The widely used methods include

- Hedonic Pricing

- $\quad$ Travel Cost Method

- Contingent Valuation method.

\section{Hedonic Pricing Method (HPM)}

This method uses existing markets like housing or labour markets to determine the value of an environmental good. The basic assumption of the method is that property values or wages shows a stream of benefits, some of which are attributable to the environmental good. The main task is to isolate that value which is attributable to the good. Hedonic pricing can be used to establish aesthetic values of biodiversity, value environmental damages and their effects on property values or wages. The HPM attempts to estimate an implicit price for non-marketed environmental attributes by looking at real markets in which those characteristics are effectively traded. Thus, clean air and peace and quiet are effectively traded in the property market since purchasers of houses and land do consider these environmental dimensions as characteristics of property (Pearce and Moran, 1994). Hedonic pricing is data intensive and becomes difficult where alternative markets are distorted or where information about environmental products is not widespread especially in developing countries.

\section{Travel Cost Method (TCM)}

The Travel Cost Method uses existing markets, determining a person's value of an environmental good from what they spend on traveling in terms of time, travel expenditures and entry fees. The travel cost method is used to estimate economic use values associated with ecosystems or sites that are used for recreation. The method can be used to estimate the economic benefits or costs resulting from: changes in access costs for a recreational site, elimination of an existing recreational site, addition of a new recreational site and changes in environmental quality at a recreational site. The basic premise of the travel cost method is that the time and travel cost expenses that people incur to visit a site represent the "price" of access to the site. Thus, peoples' willingness to pay to visit the site can be estimated based on the number of trips that they make at different travel costs. This is analogous to estimating peoples' willingness to pay for a marketed good based on the quantity demanded at different prices. TCM is based on the assumption that observed behavior can be used to derive a demand curve and to estimate value for an unpriced environmental good by treating travel costs as the surrogateprice for the non-market asset. The area under the demand curve represents the consumer surplus. However, TCM is data intensive, they rely on restrictive assumptions about consumer behavior and they are highly sensitive to the statistical methods used.

\section{Contingent Valuation Method (CVM)}

Valuation of environment is a disputable issue among statisticians and economists. While the accounting approach prefers to record only the actual financial transactions, the economic approach prefers to go beyond this, like in the case of health damages, the statisticians would prefer the cost of illness method (actual expenditure or illness), while economists also account for the loss in human capital that calls for disability adjusted life years (DALY) or statistical value of life (SVOL) or known loss of IQ in children (eg. due to pollution). Even loss of work or output due to absenteeism because of 
illness is valued in economic approach. For these, economists would like to consider opportunity cost approaches or an even subjective approach such as the contingent valuation method (CVM).

Contingent Valuation is the subject of an immense literature. CVM is used generally for the valuation of public goods especially environmental valuation (Ciriacy-Wantrup, 1947, Davis, 1963, Mitchel and Carson, 1989). The origin of the concept of contingent valuation can be traced to 1947 when Ciriacy-Wantrup considered the question of obtaining values for public goods and a survey method was suggested to obtain such values. The method was not used much till the 1960 's as the validity of the values was questioned by economists. The first recorded study using contingent valuation was done by Davis in 1961(Mitchell and Carson 1989). This was followed by a study done in 1969 (Hammack and Brown 1974).

CVM involves directly asking people, in a survey, how much they would be willing to pay for a specific environmental service or what they are willing to accept by way of compensation to tolerate a cost. Although it can be used to estimate both use and non-use values, it is used widely for estimating non-use values. This method involves creating a hypothetical market for a non-market good and invites the respondents to operate in that market. The willingness to pay (WTP) will reflect the value of the particular environmental quality (Ciriacy-Wantrup, 1947, Davis, 1963, Walsh et al, 1984, Brookshire et al, 1983, Mitchell and Carson, 1989, Choe et al, 1996). This method is also known as the stated preference technique, as the people are directly asked to state their value rather than inferring values from the actual choice. The main aim of the C.V survey is to create a hypothetical market, as close to a real market, to obtain hypothetical bids that conform to actual bids if the actual market had existed. According to the contingent valuation literature, WTP should reflect the value the community is having for a better environmental quality. The WTP of an individual is found to be dependent on several factors like income, attitude towards environment, level of knowledge etc. (Mitchell, R. C. et al 1989, Hanemann 1991, Cummings et al, 1986). It is assumed that a positive preference for something will show up in the form of a WTP for it. WTP differs from one individual to another since each one has different set of priorities. To secure a total WTP, an average of the aggregate WTP should be calculated. The hypothetical market- the questioner, questionnaire, and the respondent - must therefore be as close as possible to a real market. The respondent should be familiar with the good in question. The questioner should provide the respondent with the proper description of the resource and its potential benefits. The respondent must also be familiar with the hypothetical means of payment, say a local tax, an entry fee etc.

\section{Approaches Used to Elicit Preferences}

Generally four basic approaches are used to elicit the preference of the individuals. Although four methods are available, the choice of any method depends on the individual judgment (Bishop et al 1990).

- $\quad$ Bidding game technique: In a bidding game, individuals are asked to evaluate a potential change under a hypothetical situation and to express their WTP or WTA for a change in the level of provision of an environmental good or service. These individual estimates of WTP may be summed to provide an estimate of aggregate WTP - and hence total economic value. There are two types of bidding games - single-bid games and iterative-bid games. Single-bid games ask respondents to indicate the maximum price they would be willing to pay for an environmental good or to indicate the minimum amount of compensation they would accept for doing without that good. In the iterative or converging bid games, individuals are asked whether they would pay a given amount for the environmental good or service. The amount is then varied iteratively 
until a maximum WTP or a minimum WTA is reached. The responses are then averaged and extrapolated to arrive at the aggregate WTP or an aggregate level of compensation.

- $\quad$ Open ended: In the open-ended question format the respondents are left to devise their maximum values without the aid of additional information or bidding. The respondent is free to state any amount on being asked.

- Dichotomous choice: It offers different amounts to its respondents and asks them to say if they would be willing to pay for the amount stated in a "yes" or "no" format (Nunan, 1996). It is the first round of a bidding game.

- $\quad$ Payment card format: The method involves that respondents are offered a payment card which contains a list of potential willingness to pay amounts. Also included on the payment card are so-called benchmarks, giving the respondent an indication of how much money is currently being spent by their type of household on other public goods.

CVM has helped solve a serious problem in environmental policy analysis like the need to assign a value to non market goods and services. Surveys are used to provide analysts with the ability to ask direct questions about the economic value of environmental resources, thereby providing information that can be used as part of Cost Benefit Analysis of project program alternatives or economic assessments of resource losses. CVM is now the most widely used economics survey approach (Gregory, 2000). Contingent valuation is particularly attractive because it can estimate values where markets do not exist or where market substitutes cannot be found. CVM is widely used to measure existence values, option values, indirect use values and non-use values.

CV method, which is a simple and flexible non-market valuation method, has been severely criticized mainly on two aspects, the validity and reliability of the results and the effects of biases and errors (L.Venkatachalam, 2003). The major sources of bias are

- Strategic bias: The strategic bias is similar to the" free rider" problem. It occurs when the respondents of CVM deliberately understate or overstate the monetary value of the good in order to manipulate the policy decision in their favour It is suggested that questionnaires should be designed in such a way that the respondents are unable to behave strategically (Mitchell and Carson 1989, Hoovenagel 1990). However, most CVM studies have not found strategic bias to be significant (Pearce \& Turner, 1994).

- Hypothetical bias: Since the market created in the CV method is hypothetical, it will create hypothetical bias which is defined as the difference between the real and hypothetical payments (Cummings et al, 1986).

- Design bias: The design bias arises from three sources. The first is the starting point bias or the initial bid bias. When the questioner suggests the first bid, the starting point, it is possible that this will influence the respondent in some way by suggesting the range over which the bidding game will be played (Pearce \& Turner, 1994). The second source of the design bias is the vehicle bias or the instrument of payment, used in the approach. The respondent might be sensitive to some ways of payment, such as taxes, entrance fees, donations. The third source of the design bias is the information bias. The information quality and sequence, given to the respondent, regarding the resource in question, will influence his answers significantly. 
Environmental problems are considered as problems of non-optimal pricing and misallocation of resources. For many environmental goods there is either the complete absence of markets or they are incomplete. The presence of complete markets for each good is essential for the optimal distribution of resources in the economy and the lack of it will result in the inefficient distribution of resources. Environmental degradation and pollution occur when the market fails to take into account the true value of environmental quality to the society. The absence of a market has led to the unregulated use of the environment and its wide spread degradation. Environmental valuation techniques have provided a strong frame work in solvingtheserious problems in environmental policy analysis like the need to assign a value to non-market goods and services.

\section{REFERENCES}

1. Bishop, R.C. and T.A.Heberlein (1990), "The Contingent Valuation Method, Economic Valuation of Natural Resources: issues, theory and applications”, edited by R.L.Johnson and G.V.Johnson, WestviewPress, Oxford.

2. Blore. I and F. Nuan (1996), 'Living with Waste: Public Valuation of Solid Waste Impacts in Bangkok', Papers in the Administration of Development, 57, Development Administration Group, University of Birmingham.

3. Brookshire DS, Eubanks DS, Randal A (1983), "Estimating option price and existence values for wildlife resources", Land Economics 59:1-15.

4. Choe K.A, Whittington D, Lauria D.T (1996), "The economic benefits of surface water quality improvements in developing countries: a case study of Davao, Philippines", Land Economics; 72: 107-26.

5. Ciriacy-Wantrup SV (1947), "Capital returns from soil conservation practices”, Journal of farm economics 29:1181-96.

6. Clive L. Spash and Claudia Carter (2001), "Environmental Valuation in Europe: Findings from the Concerted Action", Cambridge Research for the Environment.

7. Cummings RG, Brookshire DS Schulze WD (Eds) (1986), "Valuing environmental goods: a state of the arts assessment of the contingent valuation method", Totowa, NJ: Roweman and Allanheld.

8. David Pearce and Kerry Turner.R (1994), "Economics and Solid Waste Management in the Developing World", CSRGE Working Paper WM 94-05.

9. David. N. Beede and David. E. Bloom (1995), “The Economics of Municipal Solid Waste”, The World Bank Research Observer, vol.10, no.2 (August 1995), pp.113-50.

10. Davis. R. (1963), "the Value of Outdoor Recreation: an Economic Study of the Marine Woods", PhD Thesis, HarvardUniversity.

11. Gamble H.B.; R.H. Downing; J. Shortle\& D.J. Epp (1982), "Effects of Solid Waste Disposal Siteson Community Development and Residential Property Values”, Institute for Research on Land and Water Resources, the PennsylvaniaStateUniversity.

12. Gregory R.S. (2000), "Valuing Environmental Policy Options: A Case Study Comparison of Multiattribute and contingent Valuation Survey Methods", Land Economics, 76(2): 151-173. 
13. Hammack, J and Brown, G.M, Jr (1974),'Waterfowl and Wetlands: Toward Bioeconomic Analysis, Baltimore, JohnHopkinsUniversity Press for Resources for the Future.

14. Hanemann M.W (1991), "Willingness to pay and willingness to accept: how much can they differ?", American Economic Review, 81:635-47.

15. Hoovenagel (1994), "The Validity of the Contingent Valuation Method. Some Aspects on the basis of three Dutch studies", Paper presented at the Congress 'Environmental cooperation and Policy in the Single European Market', Venice, Italy, April 17-20.

16. JepmaC.J and M.Munasinghe (1998), "Climate Change Policy”, Cambridge University Press, United Kingdom.

17. Mitchell RC, Carson RT (1989), "Using Surveys to Value Public Goods: the Contingent Valuation Method", Washington DC: Resource for the

18. Nunan, F. (1996), "Public opinion and solid waste in Bangkok", Local Environment, Vol. 1, No. 2, pp. 165-181.

19. Pearce, D, W, and Edward B Babier (2000), "Blue Print for a Sustainable Economy”, Earth Scan Publication Ltd. London.

20. Pearce, D., and Moran, D. (1994), "The Economic Value of Biodiversity", IUCN, Earthscan Publications, London.

21. Pearce.D.W. (1992), “Green Economics”, Environmental Values 1(1):3-13.

22. V. Santhosh, V.P. Bharadwaj and N.C. Sahu (2005), "Biodiversity and its Valuation Techniques: An Overview", In Dimensions of Environmental and Ecological Economics (2005) by Nirmal Chandra Sahu and Amita Kumari Choudhury, Universities Press.

23. Venkatachalam .L (2003), "The Contingent Valuation Method: A Review", Environmental Impact Assessment Review, ELSEVIER.

24. Walsh RG, Loomis JB, Gilman RA (1984), "Valuing option, existence and bequest demands for wilderness", Land Economics; 60:14 29. 